8. Smits M, Rutten M, Keizer E, Wensing M, Westert G, Giesen P. The Development and Performance ofAfter-Hours Primary Care in the Netherlands: A Narrative Review. Ann Intern Med. 2017;166(10):737-42.30.

9. Cowling TE, Ramzan F, Ladbrooke T, Millington H, Majeed A, Gnani $\mathrm{S}$. Referral outcomes ofattendances at general practitioner led urgent care centres in London, England: retrospective analysisof hospital administrative data. Emerg Med J. 2016;33(3):200-7.31.

10. Smits M, Hanssen S, Huibers L, Giesen P. Telephone triage in general practices: A written casescenario study in the Netherlands. Scand J Prim Health Care. 2016;34(1):28-36.

DOI https://doi.org/10.30525/978-9934-26-075-9-15

\title{
SENSITIVITY TO CEPHALOSPORINS OF OPPORTUNISTIC BACTERIA, EXCRETED IN PATIENTS WITH INFECTIOUS DISEASES OF UPPER AND LOWER RESPIRATORY TRACT
}

\section{Kovalenko N. I.}

Candidate of Biological Sciences, Associate Professor, Associate Professor at the Grynyev D. P. department of microbiology, virology and immunology

Kharkiv National Medical University

\section{Vovk O. O.}

Candidate of Medical Sciences, Associate Professor, Associate Professor at the Grynyev D. P. Department of Microbiology, Virology and Immunology Kharkiv National Medical University

\section{Novikova I. V.}

Head of a Multidisciplinary Clinical Diagnostic Laboratory Municipal non-profit enterprise of the Kharkiv regional council

"Regional clinical hospital"

Kharkiv, Ukraine

Antimicrobial resistance (AMR) is a growing problem in the $21^{\text {st }}$ century and one of the most serious jeopardies to global public health. The number of resistant microbial strains, geographic areas affected by drug resistance, and the extent of resistance in each organism are escalating. Moreover, the 
percentages of organisms exhibiting AMR, especially resistance to multiple antibiotics, are continuingly increased. Thus, disease agents that were once thought to be susceptible to antibiotics are returning in new leagues resistant to these therapies $[1,2]$.

The cephalosporins are a large group of related beta-lactam antimicrobial agents. Favorable attributes of the cephalosporins include low rates of toxicity, relatively broad spectrum of activity, and ease of administration. Various cephalosporins are effective for treatment of many conditions, including pneumonia, skin and soft tissue infections, bacteremia, and meningitis. Differences among the numerous cephalosporin antimicrobial agents are sometimes subtle; however, an understanding of these differences is essential for optimal use of these agents. As a result of widespread use of cephalosporins, bacterial resistance to these drugs is increasingly common. New, fourth-generation agents (such as cefepime) offer an alternative for the treatment of infections caused by some drug-resistant microorganisms [3].

Periodic revisions on guidelines and recommendations for treatment of the main acute infections are necessary to orient rationale and appropriate use of antibiotics. Continuous medical education and changes in physicians' and patients' behavior are required to modify the paradigm that all upper respiratory infection needs antibiotic therapy, minimizing the consequences of its inadequate and inappropriate use [4].

The aim of the research: to study the sensitivity to antibiotics of opportunistic bacteria excreted in patients with infectious diseases of upper and lower respiratory tract.

Determination of microflora sensitivity of antibiotics was carried out by agar diffusion (standard disk method) in accordance with the order of the Ministry of Health of Ukraine № 167 from 05.04.2007 [5]. 180 strains of microorganisms were analyzed in general from the patients with pharyngitis, 202 strains - from the patients with bronchitis and 211 strains - from the patients with pneumonia.

It was found in previous studies that a prominent place among causative agents of infectious diseases of upper and lower respiratory tract belongs to gram-positive coccas. Thus, the leading role in the etiology of pharynxgitis belonged to streptococci of viridans, S. aureus, S. epidermidis, S. anhemolyticus group [6]. With bronchitis, the part of coco flora was $59.2 \%$ [7], with pneumonia $-38.3 \%$ [8], among which the most widely spread were streptococci of viridans and $S$. aureus group.

In the study of the sensitivity of bacteria excreted in patients with upper respiratory diseases to antibiotics of the cephalosporin group it was found that the greatest activity was manifested by ceftriaxone and cefepime towards all strains. However, only S.epidermidis manifested absolute sensitivity to them. Ceftriaxone suppressed the growth of $95.7 \%$ of $S$. aureus and $91-95.9 \%$ of 
streptococci. The activity of cefepime was within 90-100\%. Cefoperazon demonstrated activity towards $97.6 \%$ of S.aureus and $91.4 \%$ streptococci of viridans group, as for other types - within 84.2-87.7 \%. Cefixime suppressed the growth of $86.9 \%$ of $S$. aureus and $94.7 \%$ of S.epidermidis. The activity of cefuroxime was $93 \%$ for $S$. epidermidis and S. pyogenes, as for other types the results fluctuated from $73.7 \%$ for $S$. pneumoniae to $80.3-88.6 \%$ for $S$. aureus and streptococci of viridans group. The lowest activity was recorded for ceftazidim, namely, among staphylococci the sensitivity was within $50-62,9 \%$, S. pyogenes was sensitive in $69.9 \%$, streptococci of viridans group - in $61.2 \%$ and S. pneumoniae - in $52.6 \%$. Staphylococci appeared to be more sensitive than streptococci.

In diseases of lower respiratory tract, coca flora was characterized by higher levels of resistance to cephalosporins. S. anhaemolyticus demonstrated absolute sensitivity to cefoperazone, but other species of streptococci were sensitive in 37.5-50 \% of cases. Cefoperasone suppressed the growth of $77.8 \%$ of $S$. aureus and $50 \%$ of S. epidermidis. Significantly lower activity indicators were marked for ceftriaxone towards staphylococci (S. epidermidis $-83,3 \%$, S. aureus $-65 \%$ ). Sensitivity of streptococci to ceftriaxone varied from $40 \%$ in $S$. pyogenes to $77.5 \%$ in streptococci of viridans group. The highest indices for cefepime were registered for $S$. aureus $(82.4 \%)$ and for $S$. pyogenes $(86.4 \%)$. Other types of bacteria demonstrated sensitivity to cefepime within $44,4 \%$ for $S$. anhaemolyticus and $60 \%$ for S. epidermidis.

Thus, ceftriaxone and cefepime demonstrated a high level of activity towards staphylococci and streptococci excreted from patients with pharyngitis. The growth of the resistance of bacterial flora excreted during diseases of lower respiratory tract to cephalosporins of the $3^{\text {rd }}$ and $4^{\text {th }}$ generations, namely, to ceferazone, ceftriaxone and cefepeme is marked.

\section{References:}

1. Fanta Gashe, Eshetu Mulisa, Mekidim Mekonnen, Gemechu Zeleke, "Antimicrobial Resistance Profile of Different Clinical Isolates against Third-Generation Cephalosporins", Journal of Pharmaceutics, vol. 2018, Article ID 5070742, 7 pages, 2018. https://doi.org/10.1155/2018/5070742

2. R. Noor and M. S. Munna, «Emerging diseases in Bangladesh: Current microbiological research perspective,»Tzu Chi Medical Journal, vol. 27, no. 2, pp. 49-53, 2015.

3. Marshall WF, Blair JE. The cephalosporins. Mayo Clin Proc. 1999 Feb;74(2):187-95. doi: 10.4065/74.2.187. PMID: 10069359.

4. Piltcher Otávio Bejzman, Kosugi Eduardo Macoto, Sakano Eulalia, Mion Olavo, Testa José Ricardo Gurgel, Romano Fabrizio Ricci et al. How to avoid the inappropriate use of antibiotics in upper respiratory tract infections? A position statement from an expert panel. Braz. j. otorhinolaryngol. 
[Internet]. 2018 June [cited 2021 Apr 05]; 84 (3): 265-279. Available from: http://www.scielo.br/scielo.php?script=sci_arttext\&pid=S180886942018000300265\&lng=en. http://dx.doi.org/10.1016/j.bjorl.2018.02.001.

5. Наказ МОЗ України № 167 від 05.04.07. Про затвердження методичних вказівок «Визначення чутливості мікроорганізмів до антибактеріальних препаратів». - К., 2007. - 52 с.

6. Мінухін В.В., Коваленко Н.І., Замазій Т.М., Новікова І.В., Тараненко Г.П. Етіологічна структура інфекційних захворювань ЛОР-органів. Журнал клінічних та експериментальних медичних досліджень. 2016. T. 4, № 3. C. 374-381.

7. Kovalenko N.I., Zamaziy N.M., Novikova I.V., Taranenko H.P. Etiological structure and ecological significance of opportunistic pathogens in bronchitis // World of Medicine and Biology. - 2020. - № 4 (74). - P. 68-72. doi: 10.26724/2079-8334-2020-4-74-68-72.

8. Коваленко Н.І., Замазій Т.М., Новікова І.В., Тараненко Г.П. Екологічний аналіз умовно-патогенної мікрофлори при пневмоніях. Eastern Ukrainian Medical Journal. 2019. T.7, № 2. C. 136-141.

DOI https://doi.org/10.30525/978-9934-26-075-9-16

\title{
ANALYSIS OF QUALITY OF LIFE IN PATIENTS WITH CHRONIC PANCREATITIS
}

\author{
Kotsaba Yu. Ya. \\ Candidate of Medical Sciences, \\ Assistant at the Department Of Clinical Immunology, \\ Allergology And General Patient's Care \\ Ivan Horbachevsky Ternopil National Medical University. \\ Babinets L. S. \\ Doctor of Medical Sciences, Professor, \\ Head of the Primary Health Care and General Practice \\ of Family Medicine Department \\ Ivan Horbachevsky Ternopil National Medical University \\ Ternopil, Ukraine
}

The level of human quality of life (QOL) plays an important role in health. According to the WHO «health is a state of complete physical, mental and social well-being and not merely the absence of disease or infirmity.» Therefore, the study of the level of QOL and its changes in different 